OPEN ACCESS

Edited by:

Andrews Opoku,

Kwame Nkrumah University of

Science and Technology, Ghana

Reviewed by:

Jacob Ulzen,

College of Basic and Applied Sciences, University of Ghana, Ghana

Benedicta Essel Ayamba

Soil Research Institute, Council for

Scientific and Industrial Research

(CSIR), Ghana

*Correspondence:

Peter Ebanyat

peter.ebanyat@gmail.com

Specialty section:

This article was submitted to Land, Livelihoods and Food Security, a section of the journal Frontiers in Sustainable Food Systems

Received: 02 March 2021

Accepted: 06 August 2021 Published: 30 September 2021

Citation:

Ebanyat P, de Ridder N, Bekunda M, Delve RJ and Giller KE (2021) Efficacy of Nutrient Management Options for Finger Millet Production on Degraded Smallholder Farms in Eastern Uganda. Front. Sustain. Food Syst. 5:674926. doi: 10.3389/fsufs.2021.674926

\section{Efficacy of Nutrient Management Options for Finger Millet Production on Degraded Smallholder Farms in Eastern Uganda}

\author{
Peter Ebanyat ${ }^{1 *}$, Nico de Ridder ${ }^{2}$, Mateete Bekunda ${ }^{3}$, Robert J. Delve ${ }^{4}$ and Ken E. Giller ${ }^{2}$ \\ ${ }^{1}$ Department of Agricultural Production, Makerere University, Kampala, Uganda, ${ }^{2}$ Plant Production Systems Group, \\ Wageningen University and Research Center, Wageningen, Netherlands, ${ }^{3}$ International Institute of Tropical Agriculture, \\ Arushia, Tanzania, ${ }^{4}$ International Fund for Agricultural Development, Rome, Italy
}

Poor soil fertility is a major problem constraining crop productivity in smallholder farms of sub-Saharan Africa due to inadequate nutrient replenishment. Differential management of nutrients creates areas of accumulation and depletion of nutrients within farms with the latter increasing in spatial coverage. Nutrient additions are required to increase crop production in such degraded areas. We used experimental data to evaluate the potential of inorganic fertilizers and organic manures to offset finger millet yield differences or gap between degraded fields and former kraals, which are recognized as niches for obtaining the best yields within the Teso farming system in eastern Uganda. Nitrogen $(\mathrm{N})$ and phosphorus $(\mathrm{P})$ fertilizers were sole applied at $0,30,60$, and $90 \mathrm{~kg} \mathrm{ha}^{-1}$ and in combination $(\mathrm{N}+\mathrm{P})$ at equal rates of sole application, and manure $\left(3 \mathrm{t} \mathrm{ha} \mathrm{h}^{-1}\right)$ supplemented with $\mathrm{N}\left(0,30,60\right.$, and $\left.90 \mathrm{~kg} \mathrm{ha}^{-1}\right)$ to degraded fields located in upper and middle landscape positions in Chelekura and Onamudian villages. A second control treatment of finger millet grown on soils of former kraal sites (high fertility niches) was included as a benchmark to evaluate the efficacy of nutrient management options on degraded field. Average grain yield ranged from 404 to $2,026 \mathrm{~kg} \mathrm{ha}^{-1}$ and differed significantly $(p<0.001)$ between villages and seasons. Significant effects $(p<0.05)$ of landscape position on grain yield were observed only in Onamudian village. Although the treatments significantly increased millet yields on degraded fields above the control, they could not eliminate the yield differences between degraded fields and former kraals. The largest average grain yields on degraded fields were obtained from combined application of $\mathrm{N}+\mathrm{P}$ resulting in average grain yields of 800 and $1,171 \mathrm{~kg} \mathrm{ha}^{-1}$ in Chelekura village and Onamudian village, respectively. These yield responses resulted in only 24 and $43 \%$ of yields obtained on former kraal fields in Chelekura and Onamudian, respectively. The physiological efficiencies, agronomic efficiencies, and apparent recoveries of $\mathrm{N}$ and $P$ were low; often $<25 \%$. Pot experiments conducted in a greenhouse showed that Sulphur (S) and potassium (K) were additional limiting nutrients to $\mathrm{N}$ and $\mathrm{P}$ for finger 
millet production in Chelekura and Onamudian and may partly explain the large yield differences of finger millet between fertilized fields and former kraals in the smallholder farming systems. Nutrient management strategies for sustainable millet production in these farming systems need consideration of site-specific nutrient limitations.

Keywords: integrated soil fertility management, nutrient use efficiencies, limiting nutrients, finger millet (Eleusine coracana), sub-Sahara Africa (SSA)

\section{INTRODUCTION}

The livelihood of smallholder farmers in sub-Saharan Africa (SSA) is hinged on agriculture to combat food insecurity and poverty through direct production of food and cash crops and sale of excess production to generate incomes. This is, however, threatened by poor soil fertility, now a major constraint to crop productivity in smallholder farms resulting from inadequate replenishment of nutrients removed (Holden, 2018). The magnitude of nutrient depletion varies across the different spatial scales from continent to farm (Buresh et al., 1997). Uganda is among the countries in the continent with the largest depletion rates: $20-40,3.5-6.6$, and $17-33 \mathrm{~kg} \mathrm{ha}^{-1} \mathrm{year}^{-1}$ for $\mathrm{N}, \mathrm{P}$, and $\mathrm{K}$, respectively (Smaling et al., 1997). Although negative nutrient balances are prevalent throughout SSA, areas of nutrient accumulation are created through management reinforcing heterogeneity in soil fertility and variability in crop productivity within farms (e.g., Rowe et al., 2006; Tittonell et al., 2007; Zingore et al., 2007). Continued depletion of nutrients results in poor fertility or degraded patches within farms.

The area covered by poor fertility fields in smallholder African farms is substantial and will increase if no action is taken to replenish and sustain soil fertility. Tittonell (2008) found the proportion of poor fertility fields according to farmers' categorization to account for $\sim 30 \%$ of total farm fields in six farming systems in western and central Kenya and eastern Uganda. In two villages in Pallisa district, the degraded fields covered $13-29 \%$ of the land area (Ebanyat, 2009). Together with reducing farm size, this threatens the food security of smallholders who rely on farming for their livelihood.

Finger millet (Eleusine corocana (L.) Gaertn) is an important food and nutrition crop as well as an income crop for smallholder farmers in the Teso farming system in eastern Uganda (Esele, 1989; Wanyera, 2007; Ndungu-Magiroi et al., 2017). It is rated third after maize and sorghum in order of production among smallholder farmers, and $15 \%$ of the national production is from this region [Uganda Bureau of Statistics (UBOS), 2020]. However, soil fertility depletion and labor constraints have affected its productivity $\left(<1 \mathrm{t} \mathrm{ha}{ }^{-1}\right)$ despite the availability of improved varieties (Tenywa et al., 1999; Kidoido et al., 2002; Owere et al., 2014). The farming system used to be a strongly integrated croplivestock system and sustained finger millet production until depletion of livestock through rustling, and due to decline in soil fertility and other factors has changed from a millet-based to a cassava-based farming system (Ebanyat et al., 2010a). The United Nations Convention to combat Desertification and Drought land degradation neutrality initiative proposes reversal of past degradation to improve productivity and enhance food security (Orr et al., 2017). Therefore, measures for improving/restoring fertility in degraded fields are needed for smallholders to sustain crop production and close yield differences within farms (Mueller et al., 2012).

Potential options to restore soil fertility include the use of inorganic fertilizers to optimize locally available organic inputs and addressing site-specific constraints to restore and improve soil fertility as guided in integrated soil fertility management paradigm (Vanlauwe et al., 2010). The use of inorganic fertilizers is constrained by high costs and inaccessibility, and a lack of economic returns (Morris et al., 2007; Barungi, 2012; Chianu et al., 2012; Bonilla Cedrez et al., 2020) as well as low soil organic matter (Barret et al., 2017). At the same time, amounts of organic resources available on smallholder farms are limited and their poor nutrient quality constrains their use and effectiveness in soil fertility management (Ridder et al., 2004). Combined use of organic and inorganic fertilizers is a potential approach to ameliorate soil fertility because of their complementary benefits (Vanlauwe et al., 2002; Chivenge et al., 2011; Stewart et al., 2020).

Strategies for fertility regeneration in smallholder farming systems can best be designed with the knowledge of field responsiveness to nutrient management interventions. Vanlauwe et al. (2010) propose a stepwise approach in targeting and adapting nutrient management interventions and germplasm to local variations as a way to moving toward integrated soil fertility management. The stepwise approach requires recognizable benchmarks to step up to and against which to evaluate efficacy of the intervention strategies. In the Teso farming system in eastern Uganda where this study was conducted, areas where manure accumulated over years of night corralling (former kraals) are fertile, give good yields of finger millet, and are readily observed by smallholders. We used these former kraal sites as benchmarks to assess within-farm differences in finger millet yield and to evaluate responsiveness of degraded fields to nutrient interventions in two study sites in Pallisa district. Nitrogen and phosphorus are the major nutrients limiting millet production in the low input farming systems in eastern Uganda (Tenywa et al., 1999). Research on nutrient limitations and management practices has concentrated more on major nutrients than on secondary nutrients and micronutrients (Kihara et al., 2016, 2017; Wortmann et al., 2019). A complete understanding of limiting nutrients is important for making appropriate soil and nutrient management recommendations for soil fertility remediation and needed to be done for degraded fields in the smallholder systems of eastern Uganda. We tested the hypothesis that differences in finger millet yield between the former 
kraals and degraded fields can be eliminated by application of $\mathrm{N}$ and $\mathrm{P}$ from organic and inorganic sources on degraded fields and results in improved nutrient use efficiencies by finger miller. The specific objectives of the study were (1) to determine finger millet yield response to applied nutrients of organic and inorganic origin on degraded fields and assess the extent to which yield differences between benchmark sites and degraded fields amended with nutrient inputs are reduced, (2) to determine nutrient use efficiencies by finger millet, and (3) to identify other nutrients limiting finger millet production in degraded fields.

\section{MATERIALS AND METHODS}

\section{The Study Sites}

Field experiments were conducted in two villages: Chelekura in Chelekura parish $\left(1^{\circ} 24^{\prime} \mathrm{N} ; 33^{\circ} 30^{\prime} \mathrm{E}\right)$ and Onamudian in Akadot parish $\left(1^{\circ} 11^{\prime} \mathrm{N} ; 33^{\circ} 43^{\prime} \mathrm{E}\right)$ in Pallisa district $\left(1^{\circ} 09^{\prime} \mathrm{N}, 33^{\circ} 48^{\prime} \mathrm{E}\right)$ representative of the Teso farming system in eastern Uganda. Soils of Chelekura are formed from lake deposits and those of Onamudian from basement complex rocks (granitic gneisses) (Harrop, 1970). The landscape is characterized by wide gently convex interfluves separated by wide swampy valleys (Ollier et al., 1969). The toposequence can be divided into three sub-zones: the upland zone at the summits (upper landscape positions), the midland zones located on pediments (middle landscape positions), and the valleys that may be seasonally or permanently wet (lower landscape positions). In both villages, soils are Ferralsols and Dystric Fluvisols in the uplands and valley bottoms, respectively (Ebanyat et al., 2010a).

Mean annual rainfall ranges from 900 to $1,200 \mathrm{~mm}$ and is distributed in a bimodal pattern. The first rains are from March to June and the second rains from August to October or November. A dry spell stretches from November to March. Both study sites were within the same rainfall zone of $900 \mathrm{~mm}_{\text {year }}{ }^{-1}$. Monthly temperature ranges from 15 to $36^{\circ} \mathrm{C}$, with an annual mean of $25^{\circ} \mathrm{C}$ (Yost and Eswaran, 1990). Cumulative total rainfall during the growing period of short rainy season in 2005 (2005B) was low $(\approx 400 \mathrm{~mm})$, and above normal $(\approx 615 \mathrm{~mm})$ in both short rain season of 2006 (2006B) and long rain $(\approx 580 \mathrm{~mm})$ season of 2006 (2006A) (Figure 1).

\section{Field Experiments}

Field Selection and Soil and Manure Characterization Ten degraded fields (five on upper and five on middle landscape positions) based on farmers' perceptions of fertility status and five former kraal sites last used for night corralling five years before this study were selected for experimentation in each of two study villages of Chelekura and Onamudian. Five soil subsamples were taken from each field from 0 to $20 \mathrm{~cm}$, thoroughly mixed, and by quarter sampling composite samples were obtained. Manure was collected from two (Chelekura) and three (Onamudian) former kraals and bulked together, and after thorough mixing, subsamples were taken for oven drying at $65^{\circ} \mathrm{C}$ for $48 \mathrm{~h}$ to obtain the average moisture content. Air-dried composite samples of soil $(<2 \mathrm{~mm})$ and manure samples were subjected to physico-chemical analysis at the World Agroforestry

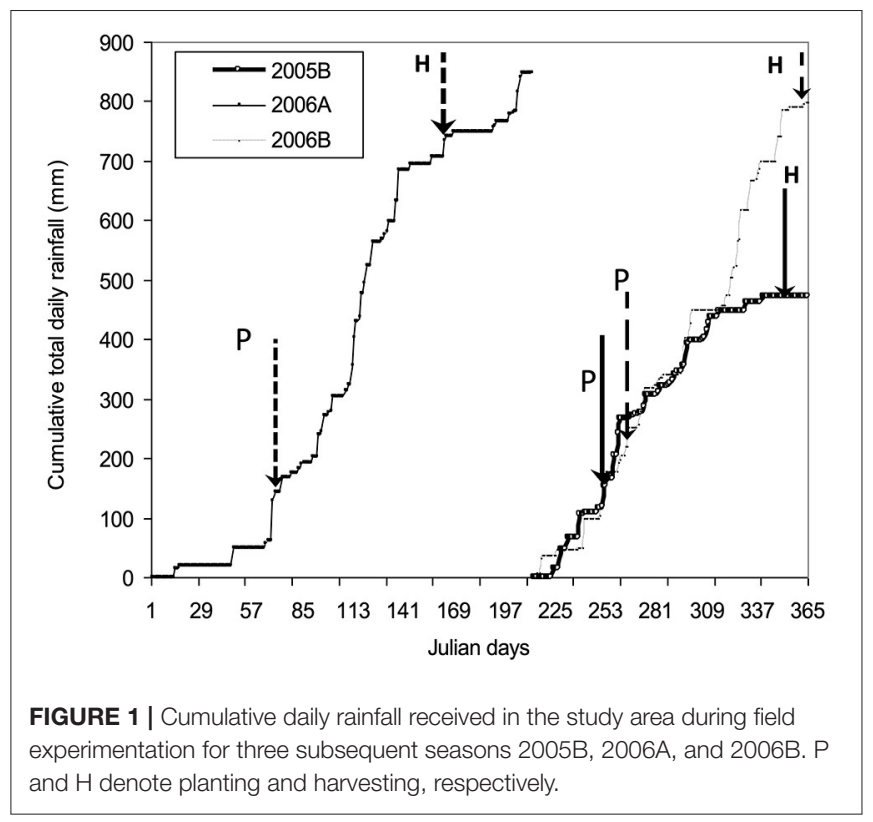

Center (ICRAF) following spectral and standard wet chemistry analysis procedures (Shepherd and Walsh, 2002). Extractable P was determined at Kawanda National Agricultural Laboratories Research Institute in Uganda using the modified Olsen method (Anderson and Ingram, 1993).

\section{Field Preparation and Experiment Establishment}

The fields were ox-plowed twice and plots of $3 \times 3 \mathrm{~m}$ demarcated. Experimental design was a randomized complete block experiment with 10 replicates (farms) per village. Kraal manure, $\mathrm{N}$ (urea), and $\mathrm{P}$ as triple super phosphate (TSP) were applied as single replicates per farm and landscape position as follows: control (with no nutrient inputs), $\mathrm{N}$ and $\mathrm{P}$ alone at rates of 30,60 , and $90 \mathrm{~kg} \mathrm{ha}^{-1}$ and combinations of $\mathrm{N}$ and $\mathrm{P}$ each at equal rates (i.e., $30 \mathrm{~N}+30 \mathrm{P}, 60 \mathrm{~N}+60 \mathrm{P}$, and $90 \mathrm{~N}+90 \mathrm{P}$ ); kraal manure at $3 \mathrm{t} \mathrm{ha}^{-1}$ and kraal manure $3 \mathrm{t} \mathrm{ha}^{-1}$ with $\mathrm{N}$ at 30,60 , and $90 \mathrm{~kg} \mathrm{ha}^{-1}$ (i.e., $\mathrm{M}+30 \mathrm{~N}, \mathrm{M}+60 \mathrm{~N}$, and $\mathrm{M}+90 \mathrm{~N}$ ). Manure and TSP fertilizer were basal applied by spreading and worked into soil with a hand hoe. Improved finger millet variety SEREMI 2 with yield potential of $2.5 \mathrm{t} \mathrm{ha}^{-1}$ and maturity period of 110 days was planted during the short rains of 2005 (2005B) at a spacing of $0.3 \mathrm{~m}$ between rows and thinned to $0.05 \mathrm{~m}$ within rows at 2 weeks after planting (WAP). Nitrogen was applied in two equal splits at first weeding (2 WAP) and second weeding (4 WAP). In the subsequent seasons of 2006A and 2006B, land preparation was done on a plot basis using a hand hoe and planting. Plots of similar size were established on former kraal sites as a second control but without addition of any nutrient inputs. The experiments were replanted in the same plots without any nutrient input additions in the long rainy season (2006A), but with nutrient inputs at the same rates during the short rainy season (2006B). All other agronomic operations were carried in the same way across the seasons. 


\section{Millet Sample Collection, Preparation, and Analysis} In 2005B, only straw was harvested because of poorly distributed rains (Figure 1) that did not allow panicle filling. In 2006, millet panicles were harvested by cutting with thumb knives (farmers' practice) and straw cut at $0.05 \mathrm{~m}$ above the ground surface from two quadrats of $1 \mathrm{~m}^{2}$ along the three middle rows of each plot. The panicles and straw samples were oven dried at Makerere University's Soil and Plant analytical laboratories at $65^{\circ} \mathrm{C}$ for $72 \mathrm{~h}$. Panicles were threshed and weights of grains and husks, and straw were obtained before they were ground to pass through a $1-\mathrm{mm}$ sieve. The samples were analyzed at the ICRAF, Nairobi, Kenya for $\mathrm{pH}$ and total (Tot.) nutrients $-\mathrm{N}$ (nitrogen), $\mathrm{K}$ (potassium), Ca (calcium), and Mg (magnesium) using NIR spectroscopy as detailed in Shepherd et al. (2003). Total $\mathrm{P}$ was determined using the wet chemistry procedure as detailed by Anderson and Ingram (1993) for plant materials at Kawanda National Agricultural Laboratories Research Institute in Uganda.

\section{Greenhouse Pot Experiment}

Bulk soils were collected from five locations within the degraded fields used for experiments at $0-20 \mathrm{~cm}$; three each from upper and middle landscape positions of each village. The samples were bulked and mixed using a manually rotated drum. The mixed soils of each village were weighed into $5-\mathrm{kg}$ pots to provide a rooting volume of $2,000 \mathrm{~cm}^{3}$, i.e., 3.48 and $3.10 \mathrm{~kg}$ for degraded soils, and 2.84 and $2.78 \mathrm{~kg}$ for former kraal soils from Chelekura and Onamudian villages, respectively. Treatments applied constituted macro- and micronutrients $\mathrm{N}, \mathrm{N}+\mathrm{P}$, $\mathrm{N}+\mathrm{P}+\mathrm{K}, \mathrm{N}+\mathrm{P}+\mathrm{K}+\mathrm{S}, \mathrm{N}+\mathrm{P}+\mathrm{K}+\mathrm{S}+\mathrm{Ca}, \mathrm{N}+\mathrm{P}+\mathrm{K}+\mathrm{S}+\mathrm{Ca}+\mathrm{Mg}$, $\mathrm{N}+\mathrm{P}+\mathrm{K}+\mathrm{S}+$ micronutrients, and $\mathrm{N}+\mathrm{P}+\mathrm{K}+\mathrm{S}+\mathrm{Ca}+\mathrm{Mg}+$ micronutrients. The source and amount of each nutrient applied $\left(\mathrm{g} \mathrm{pot}^{-1}\right)$ to soils from Chelekura and Onamudian village were $\mathrm{N}\left(\mathrm{NH}_{4} \mathrm{NO}_{3} ; 0.2429,0.2214\right), \mathrm{P}\left(\mathrm{NaH}_{2} \mathrm{PO}_{4} ; 0.1974\right.$, $0.1800), \mathrm{K}\left(\mathrm{K}_{2} \mathrm{O} ; 0.0410,0.0374\right), \mathrm{S}\left[\left(\mathrm{NH}_{4}\right)_{2} \mathrm{SO}_{4} ; 0.2104,0.1918\right]$, $\mathrm{Ca}(\mathrm{CaO} ; 0.2380,0.2170), \mathrm{Mg}(\mathrm{MgO} ; 0.1133,0.1033)$, Mo $\left(\mathrm{Na}_{2} \mathrm{MoO}_{4} ; 0.0010,0.0009\right), \mathrm{Mn}\left(\mathrm{MnSO}_{4} ; 0.0200,0.0183\right)$, $\mathrm{Cu}\left(\mathrm{CuSO}_{4} ; 0.0150,0.0137\right), \mathrm{Zn}\left(\mathrm{ZnSO}_{4} ; 0.0150,0.0137\right)$, Bo $\left(\mathrm{Na}_{2} \mathrm{~B}_{4} \mathrm{O}_{7} ; 0.0010,0.0009\right)$, and $\mathrm{Co}\left(\mathrm{CoCl}_{2} ; 0.0025,0.0023\right)$. The nutrients were dissolved in the amounts of distilled, water required to bring the soils in pots to field capacity. The pots were left to stand for 2 days and then planted with $0.5 \mathrm{~g}$ of finger millet seed of improved variety, SEREMI 2, with a potential yield of $2.5 \mathrm{t} \mathrm{ha}^{-1}$ and maturity period of 110 days. The experimental design was a complete randomized block with three replicates. At two weeks after emergence, only 20 plants were maintained per pot. Water was added after every 2 days to maintain moisture content of the pots at $70 \%$ of field capacity during the experimental period. Millet shoots were cut at $0.05 \mathrm{~m}$ from the soil surface at 8 weeks after planting (WAP) and oven dried at $65^{\circ} \mathrm{C}$ for $48 \mathrm{~h}$ to obtain shoot dry weights. Roots were recovered by washing soil from each pot through a $2-\mathrm{mm}$ sieve. The roots were then oven dried to obtain root dry weights. Total biomass was a total of recovered roots and shoot biomass.

\section{Data Calculations and Analysis}

Total nutrient uptake in straw and grain was determined as a product of straw or grain yield with mass respective percentage total $\mathrm{N}$ or total $\mathrm{P}$ and the nutrient physiological or internal nutrient efficiencies for $\mathrm{N}$ and $\mathrm{P}$ computed using the equation of Witt et al. (1999):

$$
P h E=\frac{G Y T}{U N T}
$$

where $P h E$ is physiological nutrient efficiency $\left(\mathrm{kg} \mathrm{kg}^{-1}\right), G Y T$ is grain yield for treatment $\left(\mathrm{kg} \mathrm{ha}^{-1}\right)$, and $U N T$ is the total uptake of nutrient $\left(\mathrm{kg} \mathrm{ha}^{-1}\right)$.

Agronomic efficiency and apparent nutrient recovery fractions of nutrients applied to degraded fields were computed from the following equations:

$$
A E=\frac{G Y T-G Y C}{R N}
$$

where $A E$ is agronomic efficiency $\left(\mathrm{kg} \mathrm{kg}^{-1}\right), G Y T$ is grain yield of treatment $\left(\mathrm{kg} \mathrm{ha}^{-1}\right), G Y C$ is grain yield of control treatment $(\mathrm{kg}$ $\left.\mathrm{ha}^{-1}\right), R N$ is rate of applied nutrient $\left(\mathrm{kg} \mathrm{ha}^{-1}\right)$, and

$$
A R N=\frac{U T-U C}{R N}
$$

where $A R N$ is apparent recovery of nutrient $\left(\mathrm{kg} \mathrm{kg}^{-1}\right), U T$ is total uptake of nutrient in straw and grain $\left(\mathrm{kg} \mathrm{ha}^{-1}\right), U C$ is total uptake in straw and grain in the control treatment $\left(\mathrm{kg} \mathrm{ha}^{-1}\right)$, and $R N$ is the rate of applied nutrient $\left(\mathrm{kg} \mathrm{ha}^{-1}\right)$.

Statistical analysis was performed using the linear mixedeffects models of the Genstat 11.1 statistical package for field experiments with the fixed model term: Constant+Landscape position+Treatment+Season+Landscape position $\times$ Treatment+Landscape position $\times$ Season+Treatment $\times$ Season+Landscape position $\times$ Treatment $\times$ Season, and the random term: Farm+Farm $\times$ Plot. Analysis was only conducted on data from 16 of the 20 farms because some plots were destroyed by livestock. Only data for the two seasons of 2006 are used in the analysis as the crop of 2005B season failed. For the greenhouse limiting-nutrient pot experiment, a two-way ANOVA was conducted on millet biomass and the factors compared were sites (villages) and nutrient application.

\section{RESULTS}

\section{Soil and Manure Quality}

Initial soil quality of degraded fields selected by farmers differed significantly in $\mathrm{pH}, \mathrm{SOC}$, total $\mathrm{N}$, exchangeable $\mathrm{Mg}, \mathrm{CEC}$, and total $\mathrm{P}$ between sites but not between landscape positions (Table 1). In both sites, the fields were moderately acidic and poor in extractable $\mathrm{P}\left(<10 \mathrm{mg} \mathrm{kg}^{-1}\right)$. The former kraals differed significantly between sites in $\mathrm{pH}, \mathrm{SOC}$, total $\mathrm{N}$, exchangeable $\mathrm{Mg}, \mathrm{CEC}$, and total $\mathrm{P}$, but were richer reflecting niches of good soil fertility. Manure quality varied between sites and 
TABLE 1 | Initial soil properties of degraded fields compared with poor fields and former kraals used for experimentation by landscape positions in the study villages.

\begin{tabular}{|c|c|c|c|c|c|c|c|c|c|c|c|c|}
\hline $\begin{array}{l}\text { Village/ } \\
\text { landscape } \\
\text { position }\end{array}$ & $\mathrm{pH}\left(\mathrm{H}_{2} \mathrm{O}\right)$ & $\begin{array}{c}\text { SOC } \\
(\%)\end{array}$ & $\begin{array}{c}\text { Tot N } \\
(\%)\end{array}$ & $\frac{\text { Extr. } P}{\left(\mathrm{mg} \mathrm{kg}^{-1}\right)}$ & Exc. $\mathrm{K}$ & Exc. Ca & Exc. Mg & CEC & Total P & Sand & Clay & Silt \\
\hline \multicolumn{13}{|c|}{ Degraded fields $(n=10)$} \\
\hline Upper & 6.2 & 0.59 & 0.06 & 4.7 & 0.30 & 2.5 & 0.7 & 3.2 & 0.01 & 69 & 20 & 11 \\
\hline Middle & 6.1 & 0.55 & 0.06 & 6.2 & 0.26 & 2.4 & 0.6 & 3.9 & 0.01 & 70 & 18 & 12 \\
\hline \multicolumn{13}{|c|}{ Degraded fields $(n=10)$} \\
\hline \multicolumn{13}{|l|}{ Onamudian } \\
\hline Upper & 5.3 & 0.90 & 0.11 & 4.56 & 0.30 & 2.04 & 0.86 & 8.6 & 0.03 & 60 & 27 & 13 \\
\hline Middle & 6.3 & 0.81 & 0.09 & 7.13 & 0.41 & 2.74 & 1.19 & 6.6 & 0.02 & 69 & 20 & 11 \\
\hline SED & 0.3 & 0.21 & 0.02 & 1.01 & 0.15 & 0.64 & 0.32 & 1.6 & 0.01 & 5 & 4 & 2 \\
\hline Middle & 7.3 & 1.6 & 0.16 & 18 & 1.1 & 5.2 & 1.3 & 8.4 & 0.04 & 66 & 23 & 11 \\
\hline SED & 0.32 & 0.39 & 0.03 & 3.9 & 0.2 & 0.9 & 0.11 & 1.3 & 0.01 & 3.8 & 3.1 & 1 \\
\hline \multicolumn{13}{|c|}{ Former kraals $(n=10)$} \\
\hline \multicolumn{13}{|l|}{ Onamudian } \\
\hline Upper & 6.6 & 2.1 & 0.20 & 24 & 0.7 & 5.4 & 2.0 & 12.0 & 0.06 & 59 & 26 & 15 \\
\hline Middle & 6.7 & 2.4 & 0.23 & 21 & 0.8 & 5.1 & 1.70 & 11.2 & 0.05 & 66 & 25 & 9 \\
\hline SED & 0.4 & 0.34 & 0.04 & 6.2 & 0.16 & 1.6 & 0.22 & 1.40 & 0.02 & $2.6^{*}$ & 1.95 & 1.5 \\
\hline SED (village) & $0.24^{*}$ & $0.25^{\star}$ & $0.03^{\star}$ & 3.5 & 0.13 & 0.88 & $0.13^{\star \star \star}$ & $0.89^{\star \star}$ & $0.01^{*}$ & 2.5 & 1.71 & 1.4 \\
\hline
\end{tabular}

Significance: ${ }^{*} p<0.05 ;{ }^{* *} p<0.01 ;{ }^{* \star \star} p<0.001$.

SOC, soil organic carbon; Tot N, total nitrogen; Extr. P, extractable P (Olsen); Exc. K, exchangeable K; Exc. Ca, exchangeable Ca; Exc. Mg, exchangeable Mg; CEC, cation exchange capacity; SED, standard error of difference.

TABLE 2 | Chemical properties of cattle manure used in the experiments.

\begin{tabular}{|c|c|c|c|c|c|c|c|c|}
\hline Site/season & $\begin{array}{c}\mathrm{pH} \\
\left(\mathrm{H}_{2} \mathrm{O}, 1: 2.5\right)\end{array}$ & $\begin{array}{c}\text { Total C } \\
(\%)\end{array}$ & Total N (\%) & Total P (\%) & Total K (\%) & Total Ca (\%) & Total Mg (\%) & $\mathrm{C} / \mathrm{N}$ ratio \\
\hline \multicolumn{9}{|l|}{ Chelekura } \\
\hline $2006 B$ & 9.5 & 7.99 & 0.71 & 0.26 & 0.94 & 0.62 & 0.19 & 11 \\
\hline \multicolumn{9}{|l|}{ Onamudian } \\
\hline
\end{tabular}

seasons, and was poor in carbon (Table 2). The narrow C:N ratio (8-11) implies that manure used in both study sites was well decomposed.

\section{Finger Millet Yield, Nutrient Uptake, and Nutrient Use Efficiencies}

Analysis of yield, nutrient uptake, and physiological efficiencies data showed significant $(p<0.001)$ differences between sites; thus, further analysis was conducted by site to assess landscape position, treatment, season, and their interaction effects. Landscape position was significant $(p<0.05)$ for only $\mathrm{N}$ uptake in Chelekura village and for grain yield and physiological $\mathrm{P}$ efficiency in Onamudian village. Treatments were highly significantly different $(p<0.001)$ for almost all of the variables in both locations with the exceptions of $\mathrm{PhEP}$ and ANR in Chelekura. Landscape $\times$ treatment interactions were rare and only for PhEP and AEP in Chelekura and Onamudian villages, respectively.

\section{Seasonal Variations}

The relationship between inherent soil fertility, rates of fertilizer, and yield was investigated with the aid of threequadrant diagrams (Wit, 1992). With this procedure, fertilizer application and yield responses (quadrant i) are split into the relationships between total nutrient uptake and yield (quadrant ii) and between fertilizer rates and total nutrient 


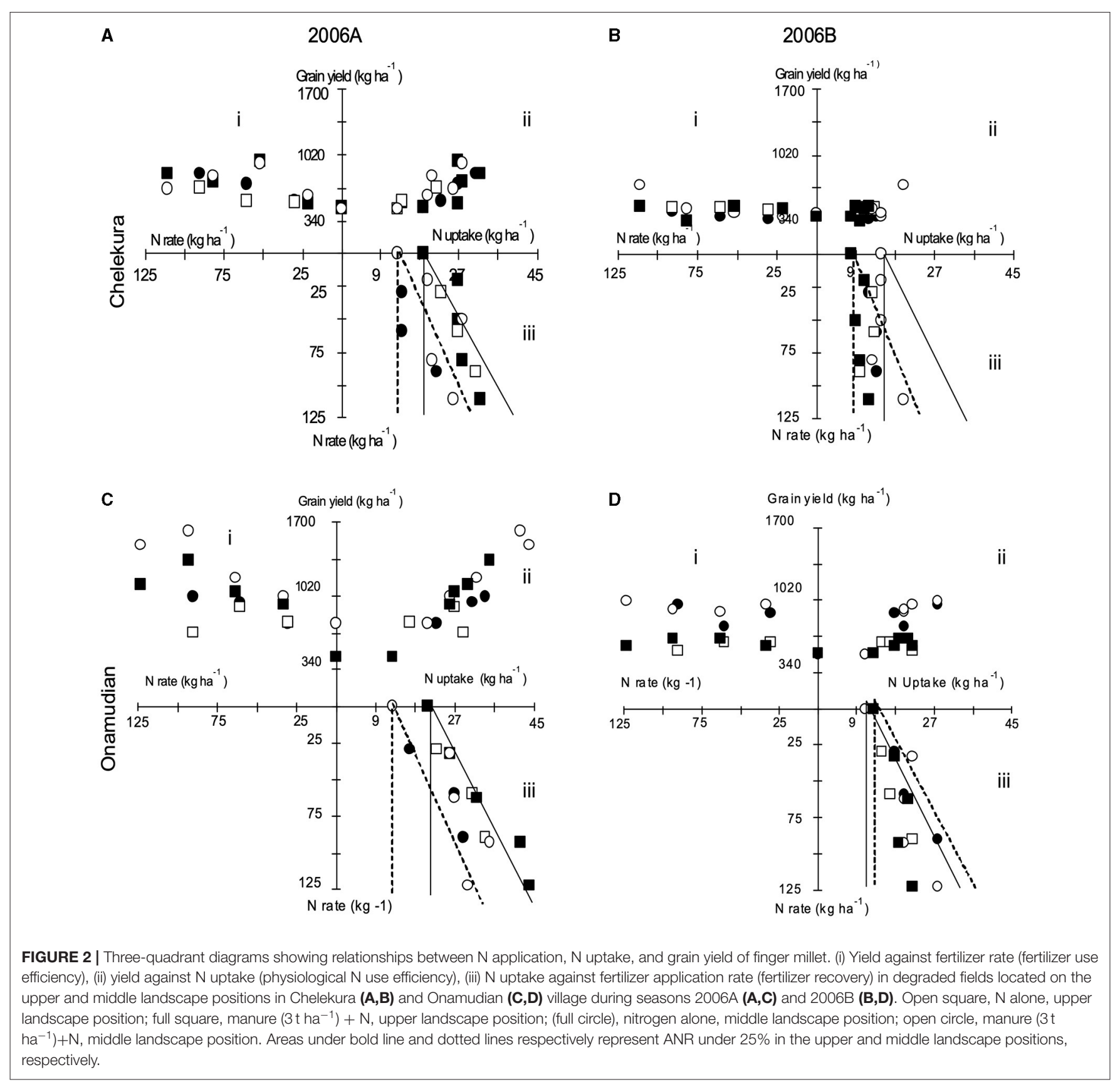

uptake (quadrant iii), for N (Figure 2) and P (Figure 3). These relationships were plotted for the grain yield of finger millet for treatments applied to degraded fields during seasons 2006A and $2006 \mathrm{~B}$ by landscape position. Yield responses are related to nutrient uptake, which was influenced by the apparent nutrient recovery. Apparent nutrient recoveries were also determined by the indigenous nutrient supply by the soils and varied between seasons.

The indigenous supply of $\mathrm{N}$ was larger in both seasons in the upper than middle position with $19 \mathrm{~kg} \mathrm{~N} \mathrm{ha}^{-1}$ and $13 \mathrm{~kg} \mathrm{~N} \mathrm{ha}^{-1}$ (2006A) and $15 \mathrm{~kg} \mathrm{~N} \mathrm{ha}^{-1}$ and $8 \mathrm{~kg} \mathrm{~N} \mathrm{ha}^{-1}$ (2006B) in Chelekura village. In Onamudian, the indigenous supply of $\mathrm{N}$ was larger in the upper landscape position $\left(21 \mathrm{~kg} \mathrm{~N} \mathrm{ha}^{-1}\right)$ than in the middle position (13 kg N ha-1) in 2006A. Indigenous supply of $\mathrm{N}$, however, declined in the upper landscape position $\left(11 \mathrm{~kg} \mathrm{~N} \mathrm{ha}^{-1}\right)$ but remained the same in the middle landscape position $(13 \mathrm{~kg}$ $\mathrm{N} \mathrm{ha}^{-1}$ ) in the $2006 \mathrm{~B}$ season. Apparent $\mathrm{N}$ recoveries (ANR) were $<25 \%$ for both the $\mathrm{N}$-only treatments and manure $+\mathrm{N}$ treatments on both landscape positions in Chelekura village in each of the seasons. In Onamudian, only a few cases did it approach $40 \%$. These low recoveries contributed to small total $\mathrm{N}$ uptake, which in turn determined the generally rather flat yield response curves in both villages (quadrant $\mathrm{i}$ ). The responses in $2006 \mathrm{~A}$ are due to nutrient application in $2005 \mathrm{~B}$ and those 


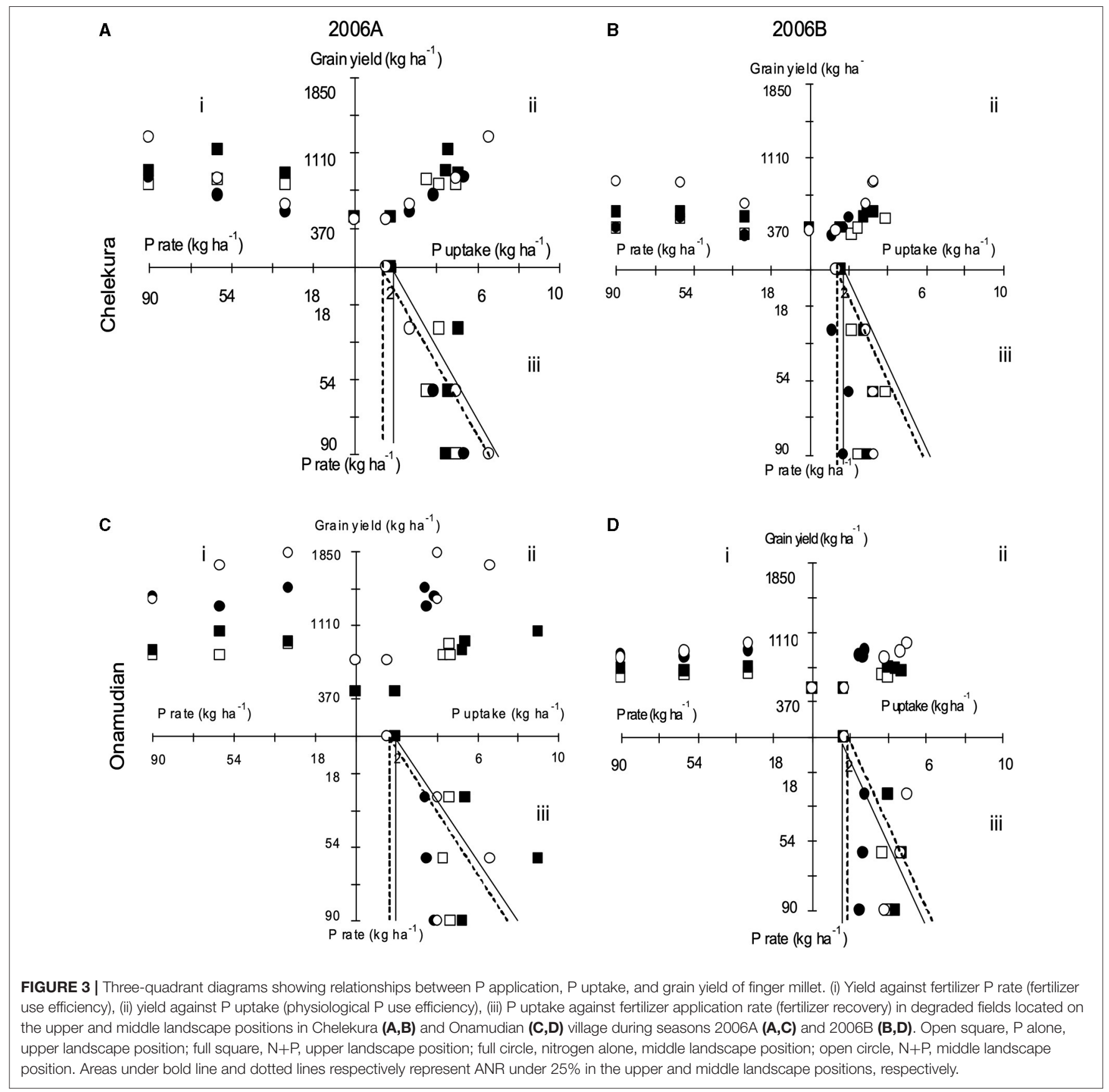

for $2006 \mathrm{~B}$ are due to nutrient application that season, plus any residual effect of $\mathrm{P}$ that was applied earlier. Application of manure with $\mathrm{N}$ occasionally gave slight increases in ANR, which was reflected in responses in $\mathrm{N}$ uptake and yield signifying an additive benefit from manure application, especially in the 2006A season.

The indigenous $\mathrm{P}$ supply was higher in 2006A than 2006B season for both landscape positions (Figure 3). In Chelekura village, indigenous $\mathrm{P}$ supply in the upper position $(1.79 \mathrm{~kg} \mathrm{P}$ $\left.\mathrm{ha}^{-1}\right)$ was larger than in the middle position $\left(1.59 \mathrm{~kg} \mathrm{P} \mathrm{ha}^{-1}\right)$ in $2006 \mathrm{~A}$ and $1.61 \mathrm{~kg} \mathrm{P} \mathrm{ha}^{-1}$ in the upper position and $1.34 \mathrm{~kg}$
$\mathrm{P} \mathrm{ha} \mathrm{h}^{-1}$ in the middle position in 2006B. Because of larger total $\mathrm{P}$ reserves, indigenous $\mathrm{P}$ supply in Onamudian village was larger than in Chelekura village: $1.93 \mathrm{~kg} \mathrm{P} \mathrm{ha}^{-1}$ (upper position) and $1.58 \mathrm{~kg} \mathrm{P} \mathrm{ha}^{-1}$ (middle position) in $2006 \mathrm{~A}$ and $1.67 \mathrm{~kg} \mathrm{P} \mathrm{ha}^{-1}$ (upper position) and $1.70 \mathrm{~kg} \mathrm{P} \mathrm{ha}^{-1}$ (middle position) in 2006B. Apparent $\mathrm{P}$ recoveries (APR) were also small and usually $<25 \%$ for both the $\mathrm{P}$ only and $\mathrm{N}+\mathrm{P}$ treatments. $\mathrm{P}$ uptake was higher in $\mathrm{N}+\mathrm{P}$ treatments than sole application of $\mathrm{P}$ in both study villages, implying that $\mathrm{N}$ and $\mathrm{P}$ were limiting in both sites. Yield responses were higher in 2006A than 2006B. 
TABLE 3 | Average straw yield, grain yield, total nutrient uptake and internal nutrient use efficiencies, agronomic efficiencies, and recovery efficiencies of finger millet as affected by application of nutrient inputs to degraded fields on the upper and middle landscape positions in Chelekura village, 2 seasons of 2006.

\begin{tabular}{|c|c|c|c|c|c|c|c|c|c|c|c|}
\hline \multirow[t]{2}{*}{$\begin{array}{l}\text { Landscape position/ } \\
\text { Treatment }\end{array}$} & Straw yield & \multirow[t]{2}{*}{$\begin{array}{l}\text { Grain } \\
\text { yield }\end{array}$} & \multirow{2}{*}{$\frac{\text { RYI }}{\%}$} & \multirow{2}{*}{\multicolumn{2}{|c|}{$\frac{\text { N uptake } \quad \text { P uptake }}{\text { kg ha }^{-1}}$}} & \multirow[t]{2}{*}{ PhEN } & \multirow[t]{2}{*}{ PhEP } & AEN & \multirow[t]{2}{*}{ AEP } & \multirow[t]{2}{*}{ ARN } & \multirow[t]{2}{*}{ ARP } \\
\hline & $\mathbf{k g ~ h a}^{-1}$ & & & & & & & $\mathbf{k g ~} \mathbf{k g}^{-1}$ & & & \\
\hline \multicolumn{12}{|l|}{ Upper } \\
\hline Control & 1,043 & 443 & 0 & 17 & 1.7 & 28 & 276 & - & - & - & - \\
\hline $30 N$ & 1,305 & 441 & -0.5 & 18 & 2.6 & 26 & 194 & -0.1 & - & 0.06 & - \\
\hline $60 N$ & 1,341 & 550 & 24 & 21 & 2.4 & 28 & 251 & -0.1 & - & 0.08 & - \\
\hline $90 N$ & 1,649 & 625 & 41 & 23 & 3.0 & 28 & 228 & 1.9 & - & 0.05 & - \\
\hline $30 P$ & 1,212 & 571 & 29 & 16 & 3.2 & 33 & 205 & - & 0.6 & - & 0.09 \\
\hline $60 P$ & 1,268 & 668 & 51 & 15 & 3.4 & 52 & 223 & - & 6.0 & - & 0.05 \\
\hline $90 P$ & 1,251 & 598 & 35 & 18 & 3.6 & 33 & 192 & - & 1.7 & - & 0.03 \\
\hline Manure* & 1,255 & 552 & 25 & 21 & 3.5 & 36 & 251 & 10.3 & 43.3 & 0.38 & 0.51 \\
\hline$M+30 N$ & 1,510 & 685 & 55 & 21 & 3.4 & 33 & 235 & 0.5 & 5.6 & 0.01 & 0.21 \\
\hline $\mathrm{M}+60 \mathrm{~N}$ & 1,650 & 783 & 77 & 23 & 2.6 & 28 & 237 & 2.6 & 44.0 & 0.02 & 0.28 \\
\hline$M+90 N$ & 2,012 & 766 & 73 & 26 & 4.1 & 33 & 240 & 2.8 & 54.3 & 0.03 & 0.28 \\
\hline $30 N+30 P$ & 1,516 & 715 & 61 & 21 & 3.9 & 34 & 211 & 9.0 & 9.1 & 0.16 & 0.09 \\
\hline $60 N+60 P$ & 2,109 & 854 & 93 & 27 & 4.0 & 33 & 252 & 6.8 & 6.0 & 0.20 & 0.05 \\
\hline $90 \mathrm{~N}+90 \mathrm{P}$ & 2,322 & 749 & 69 & 25 & 3.7 & 34 & 228 & 3.4 & 3.4 & 0.12 & 0.04 \\
\hline \multicolumn{12}{|l|}{ Middle } \\
\hline Control & 1,024 & 418 & 0 & 10 & 1.5 & 43 & 285 & - & - & - & - \\
\hline $30 \mathrm{~N}$ & 1,147 & 493 & 18 & 13 & 2.1 & 37 & 254 & 2.5 & - & 0.12 & - \\
\hline $60 N$ & 1,193 & 404 & -3 & 14 & 1.5 & 35 & 263 & 1.8 & - & 0.11 & - \\
\hline $90 \mathrm{~N}$ & 1,172 & 576 & 38 & 16 & 2.4 & 42 & 265 & 1.7 & - & 0.07 & - \\
\hline $30 P$ & 1,425 & 679 & 62 & 18 & 3.5 & 42 & 234 & - & -1.1 & - & 0.06 \\
\hline $60 P$ & 1,185 & 600 & 44 & 17 & 2.9 & 37 & 217 & - & 3.6 & - & 0.04 \\
\hline $90 P$ & 1,408 & 646 & 55 & 18 & 3.5 & 35 & 202 & - & 2.8 & - & 0.02 \\
\hline Manure $^{\star}$ & 1,065 & 462 & 11 & 15 & 2.8 & 30 & 239 & 11.5 & 46.8 & 0.45 & 0.43 \\
\hline$M+30 N$ & 1,175 & 709 & 70 & 19 & 3.5 & 45 & 223 & 7.5 & 76.9 & 0.26 & 0.74 \\
\hline$M+60 N$ & 1,536 & 628 & 50 & 17 & 2.1 & 37 & 229 & 12.6 & 29.3 & 0.64 & 0.24 \\
\hline $\mathrm{M}+90 \mathrm{~N}$ & 1,850 & 569 & 36 & 23 & 2.2 & 24 & 256 & 2.3 & 52.8 & 0.11 & 0.26 \\
\hline $30 N+30 P$ & 1,240 & 625 & 50 & 16 & 3.6 & 40 & 181 & 6.6 & 5.2 & 0.37 & 0.06 \\
\hline $60 N+60 P$ & 1,633 & 858 & 105 & 23 & 4.1 & 38 & 217 & 7.7 & 11.5 & 0.22 & 0.07 \\
\hline $90 \mathrm{~N}+90 \mathrm{P}$ & 1,846 & 1,069 & 156 & 26 & 4.9 & 40 & 227 & 6.9 & 6.3 & 0.24 & 0.05 \\
\hline \multicolumn{12}{|l|}{ SED } \\
\hline LP & 330ns & $156 n s$ & & $3.2^{*}$ & $0.8 \mathrm{~ns}$ & $7 \mathrm{~ns}$ & $6 n s$ & $4.8 \mathrm{~ns}$ & $27 n s$ & $0.21 \mathrm{~ns}$ & $0.19 \mathrm{~ns}$ \\
\hline TRT & 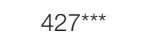 & $201^{\star \star}$ & & $3.3^{\star \star \star \star}$ & $1.1^{\star \star \star}$ & 9ns & $29^{\star \star \star}$ & $5.2^{*}$ & $26.8^{\star}$ & $0.22 \mathrm{~ns}$ & $0.21^{\star * *}$ \\
\hline$L P \times T R T$ & $380 \mathrm{~ns}$ & 180ns & & $3.2 \mathrm{~ns}$ & $0.9 \mathrm{~ns}$ & $8 n s$ & $18^{\star \star \star}$ & $5.7 \mathrm{~ns}$ & $28.5 n s$ & $0.22 \mathrm{~ns}$ & $0.20 \mathrm{~ns}$ \\
\hline
\end{tabular}

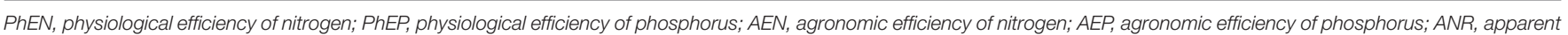

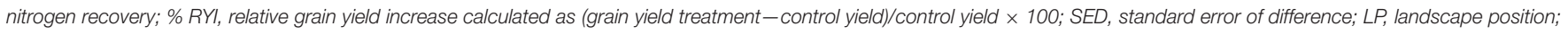
TRT, treatment.

${ }^{*}$ Amount of $N$ and $P$ in manure is computed based on \% $N$ and $P$ in manure; see Table 2.

Significance: $n s$, not significant; ${ }^{*} p<0.05 ;{ }^{* \star} p<0.01 ;{ }^{* * *} p<0.001$.

\section{Across-Season Analysis}

Average straw and grain yield significantly differed between treatments $(p<0.01)$ but not between landscape positions nor treatment $\times$ landscape position interaction in Chelekura village (Table 3). Yield increased with increasing levels of nutrients and combinations in each landscape position. Grain yield ranged from 443 to $854 \mathrm{~kg} \mathrm{ha}^{-1}$ and 418 to $1,069 \mathrm{~kg} \mathrm{ha}^{-1}$ in the upper and middle landscape positions, respectively. The range of yield increase above the control or percent relative yield increase (RYI) was from $-0.1 \%(30 \mathrm{~N})$ to $93 \%(60 \mathrm{~N}+60 \mathrm{P})$ on the upper landscape position and from $-3 \%(60 \mathrm{~N})$ to $156 \%(90 \mathrm{~N}+90 \mathrm{P})$ in the middle landscape position and was generally better on combination of $\mathrm{N}+\mathrm{P}$ and manure $+\mathrm{N}$. Uptake of $\mathrm{N}$ was significantly $(p<0.05)$ higher on the upper than middle landscape position. It also differed significantly $(p<0.001)$ between treatments with the highest uptake usually obtained from the $\mathrm{N}+\mathrm{P}$ treatments. The average $\mathrm{N}$ uptake ranged from 17 (control) to $27 \mathrm{~kg} \mathrm{ha}^{-1}(60 \mathrm{~N}+60 \mathrm{P})$ on the upper landscape 
TABLE 4 | Average straw yield, grain yield, total nutrient uptake and internal nutrient use efficiencies, agronomic efficiencies, and recovery efficiencies of finger millet as affected by application of nutrient inputs to degraded fields on the upper and middle landscape positions in Onamudian village, 2 seasons of 2006.

\begin{tabular}{|c|c|c|c|c|c|c|c|c|c|c|c|}
\hline \multirow[t]{2}{*}{$\begin{array}{l}\text { Landscape position / } \\
\text { Treatment }\end{array}$} & Straw yield & Grain yield & $\begin{array}{c}\text { GY } \\
\text { increase }\end{array}$ & $\mathrm{N}$ uptake & P uptake & PhEN & PhEP & AEN & AEP & ARN & ARP \\
\hline & \multicolumn{2}{|c|}{$\mathbf{k g ~ h a} \mathbf{a}^{-1}$} & $\%$ & \multicolumn{2}{|c|}{$\mathbf{k g ~ h a} \mathbf{a}^{-1}$} & \multicolumn{6}{|c|}{$\mathbf{k g ~ k g}^{-1}$} \\
\hline \multicolumn{12}{|l|}{ Upper } \\
\hline Control & 1,055 & 620 & 0 & 15 & 1.8 & 44 & 262 & - & - & - & - \\
\hline $30 N$ & 1,381 & 826 & 33 & 20 & 3 & 41 & 217 & 7.0 & - & 0.15 & - \\
\hline $30 \mathrm{P}$ & 1,658 & 1,202 & 94 & 23 & 4.4 & 53 & 235 & - & 19.6 & - & 0.09 \\
\hline $60 P$ & 1,938 & 1,077 & 74 & 23 & 4 & 50 & 200 & - & 7.7 & - & 0.05 \\
\hline $90 \mathrm{P}$ & 2,053 & 1,131 & 82 & 27 & 4.3 & 44 & 190 & - & 5.7 & - & 0.04 \\
\hline Manure & 1,598 & 993 & 60 & 24 & 3.7 & 42 & 230 & 13.9 & 67.1 & 0.34 & 0.22 \\
\hline$M+30 N$ & 1,564 & 1,037 & 67 & 26 & 3.7 & 41 & 233 & 6.6 & 37.2 & 0.15 & 0.19 \\
\hline $60 N+60 P$ & 2,527 & 1,889 & 205 & 37 & 8.2 & 56 & 157 & 12.0 & 12.2 & 0.31 & 0.10 \\
\hline $90 N+90 P$ & 2,803 & 1,102 & 78 & 32 & 4.4 & 39 & 151 & 4.8 & 5.0 & 0.20 & 0.05 \\
\hline \multicolumn{12}{|l|}{ Middle } \\
\hline Control & 823 & 482 & 0 & 13 & 1.6 & 39 & 250 & - & - & - & - \\
\hline $30 \mathrm{~N}$ & 889 & 695 & 44 & 16 & 2.9 & 44 & 211 & 7.1 & - & 0.09 & - \\
\hline $60 N$ & 1,524 & 766 & 59 & 22 & 3.5 & 37 & 156 & 4.7 & - & 0.15 & - \\
\hline $90 N$ & 2,044 & 605 & 26 & 26 & 2.5 & 24 & 118 & 1.4 & - & 0.14 & - \\
\hline 30P & 1,174 & 798 & 66 & 19 & 3.1 & 45 & 214 & - & 10.5 & - & 0.05 \\
\hline $60 P$ & 2,044 & 734 & 52 & 23 & 3.1 & 34 & 154 & - & 4.2 & - & 0.06 \\
\hline $90 P$ & 1,387 & 717 & 49 & 20 & 3.2 & 38 & 167 & - & 2.6 & - & 0.02 \\
\hline Manure & 1,417 & 790 & 64 & 24 & 3.7 & 34 & 159 & 12.5 & 31.5 & 0.40 & 0.29 \\
\hline \multicolumn{12}{|l|}{ SED } \\
\hline LP & $347 \mathrm{~ns}$ & $153^{*}$ & & $3.8 \mathrm{~ns}$ & $0.59 \mathrm{~ns}$ & 4.0ns & $25^{\star \star}$ & $4.03 \mathrm{~ns}$ & $12.4 \mathrm{~ns}$ & $0.09 \mathrm{~ns}$ & $0.08 \mathrm{~ns}$ \\
\hline TRT & $453^{\star \star \star}$ & $195^{\star \star \star}$ & & $4.5^{\star \star \star}$ & $0.76^{\star \star \star}$ & $4.3^{\star \star \star}$ & $26^{\star \star \star}$ & $4.65^{\star \star \star}$ & $13.3^{\star \star \star}$ & $0.11^{\star \star \star}$ & $0.09^{\star \star \star}$ \\
\hline $\mathrm{LP} \times \mathrm{TRT}$ & $401 \mathrm{~ns}$ & $175 \mathrm{~ns}$ & & $4.2 \mathrm{~ns}$ & $0.68^{\star}$ & $4.29 \mathrm{~ns}$ & $26 n s$ & $4.36 \mathrm{~ns}$ & $12.9^{\star}$ & $0.10 \mathrm{~ns}$ & $0.09 n s$ \\
\hline
\end{tabular}

PhEN, physiological efficiency of nitrogen; PhEP, physiological efficiency of phosphorus; AEN, agronomic efficiency of nitrogen; AEP, agronomic efficiency of phosphorus; ANR, apparent nitrogen recovery; \% RYI, relative grain yield increase calculated as (grain yield treatment-control yield)/control yield $\times 100$; SED, standard error of difference; LP, landscape position; TRT, treatment.

${ }^{*}$ Amount of $N$ and $P$ in manure is computed based on $\% N$ and $P$ in manure; see Table 2

Significance: ns, not significant; ${ }^{*} p<0.05 ;{ }^{* *} p<0.01 ;{ }^{* * *} p<0$.

position and from 10 (control) to $26 \mathrm{~kg} \mathrm{ha}^{-1}(90 \mathrm{~N}+90 \mathrm{P})$ in the middle landscape position. Average $\mathrm{P}$ uptake also differed significantly $(p<0.001)$ between treatments. Treatments that received $\mathrm{P}$ fertilizer generally resulted in significantly larger $\mathrm{P}$ uptake compared with the control. Only physiological $\mathrm{P}$ efficiencies differed significantly $(p<0.001)$ between treatments and by treatment $\times$ landscape position and ranged from 192 to $276 \mathrm{~kg} \mathrm{~kg}^{-1}$ and 181 to $285 \mathrm{~kg} \mathrm{~kg}^{-1}$ in the upper landscape and middle landscape positions, respectively.
Agronomic efficiencies of $\mathrm{N}$ (AEN) were higher for manure $+\mathrm{N}$ and $\mathrm{N}+\mathrm{P}$ treatments in both the upper and middle landscape positions. Manure treatments resulted in the highest agronomic efficiencies of P (AEP) ranging from 5.6 to $54 \mathrm{~kg}_{\text {grain }} \mathrm{kg}^{-1} \mathrm{P}$ and from 29 to $77 \mathrm{~kg} \mathrm{~kg}^{-1}$ in the upper and middle landscape positions, respectively. Apparent $\mathrm{N}$ recovery (ARN) was $<1 \mathrm{~kg} \mathrm{~kg}^{-1}$ for all the treatments although it tended to be better for manure-based and $\mathrm{N}+\mathrm{P}$ treatments. Apparent recoveries of $\mathrm{P}$ were also small although again they tended to be 
higher between 0.2 and $0.74 \mathrm{~kg} \mathrm{~kg}^{-1}$ for manure treatments in the upper and middle landscape positions.

Trends in average responses of yield, uptake, and physiological efficiencies in Onamudian village (Table 4) were similar to those in Chelekura with some minor differences. Grain yield was significantly $(p<0.05)$ larger on the upper than the middle landscape position. The RYI ranged from 33 to $205 \%$ in the upper landscape position and 26 to $108 \%$ in the middle landscape position. The yields in Onamudian village were higher than those in Chelekura village. $\mathrm{N}$ uptake was not significantly different between landscape positions, but physiological $\mathrm{N}$ efficiencies were significantly higher $(p<0.001)$ between treatments in the upper than in the middle landscape positions. They ranged from 32 to $57 \mathrm{~kg} \mathrm{ha}^{-1}$ and from 24 to $57 \mathrm{~kg} \mathrm{~kg}^{-1}$ on the upper and middle landscape positions, respectively. Physiological $\mathrm{P}$ efficiencies were significantly higher in the upper (151 to $262 \mathrm{~kg}$ $\mathrm{kg}^{-1}$ ) compared with the middle landscape position (118 to $250 \mathrm{~kg} \mathrm{~kg}^{-1}$ ).

Agronomic efficiencies (AE), apparent $\mathrm{N}$ recovery fractions (ANR), and apparent $\mathrm{P}$ recovery (APR) from $\mathrm{N}, \mathrm{P}$, and manure $+\mathrm{N}$ applied to degraded fields were generally low. The AEN ranged from 3.7 to $26 \mathrm{~kg}$ grain yield per kilogram of $\mathrm{N}$ with usually better AEN recorded with manure $\mathrm{N}+\mathrm{P}$ at equal rates of 30 or $60 \mathrm{~kg} \mathrm{ha}^{-1}$ implying a complementarity role of $\mathrm{P}$ in agronomic use of $\mathrm{N}$. The AEP were higher where manure and $\mathrm{N}$ were applied in both the upper and middle landscape positions reaching a highest level of $83.5 \mathrm{~kg}_{\text {grain }} \mathrm{kg}^{-1}$ of $\mathrm{P}$ with $\mathrm{M}+60 \mathrm{~N}$ in the upper landscape position. The range for ANR was $0.10-0.53 \mathrm{~kg} \mathrm{~kg}^{-1}$ and for APR from 0.02 to $0.62 \mathrm{~kg} \mathrm{~kg}^{-1}$.

\section{Within-Farm Yield Differences}

Across application rates, grain yield responses to application of $\mathrm{N}, \mathrm{P}$, manure, manure $+\mathrm{N}$, and $\mathrm{N}+\mathrm{P}$ treatments on degraded fields were variable, but yields were increased above the control treatment (Figure 4). Responses were larger in Onamudian than Chelekura village although in both villages yields obtained with fertilizers were always less than those on the former kraal sites. In Chelekura village, all treatments produced yields $<1,000 \mathrm{~kg} \mathrm{ha}^{-1}$, and in Onamudian village, only manure $+\mathrm{N}\left(1,036 \mathrm{~kg} \mathrm{ha}^{-1}\right)$ and $\mathrm{N}+\mathrm{P}\left(1,171 \mathrm{~kg} \mathrm{ha}^{-1}\right)$ produced yields $>1,000 \mathrm{~kg} \mathrm{ha}^{-1}$. The trend in yield responses relative to the control were manure $(0.21)$ $<\mathrm{P}(0.45)<\mathrm{N}(0.47)<$ manure $+\mathrm{N}(0.62)<\mathrm{N}+\mathrm{P}(0.88)$ in Chelekura and $(0.43)<\mathrm{N}(0.64)<\mathrm{P}(0.70)<$ manure $+\mathrm{N}(0.87)$ $<\mathrm{N}+\mathrm{P}(1.11)$ in Onamudian village. Treatment application to degraded fields resulted in closing of gaps in grain yields between former kraals and the control treatment $\left(1,532 \mathrm{~kg} \mathrm{ha}^{-1}\right)$ by $6 \%$ (manure) to $24 \%(\mathrm{~N}+\mathrm{P})$ in Chelekura village and in Onamudian village $\left(1,442 \mathrm{~kg} \mathrm{ha}^{-1}\right)$ by $16 \%$ (manure) to $43 \%(\mathrm{~N}+\mathrm{P})$. Overall, grain yield responded more strongly to $\mathrm{N}+\mathrm{P}$ application than to sole applications of either $\mathrm{N}$ or $\mathrm{P}$, implying that both nutrients are limiting on both sites.

\section{Other Limiting Nutrients}

In the pot experiment conducted to explore whether nutrients other than $\mathrm{N}$ and $\mathrm{P}$ were limiting crop response in the field experiments (Figure 5), main effects of village and treatments were highly significant $(p<0.001)$ and village $\times$ treatment were significant $(p<0.05)$ on millet biomass. $\mathrm{N}$ alone significantly increased biomass yields of finger millet in degraded soils from Onamudian but not in the soils from Chelekura. When $\mathrm{N}$ and $\mathrm{P}$ were applied together, shoot growth increased much more strongly in soils from Chelekura and the increase in growth was doubled on Onamudian soils compared with the sole nutrients. Addition of $\mathrm{K}$, together with $\mathrm{N}$ and $\mathrm{P}$, significantly increased growth above the $\mathrm{N}+\mathrm{P}$ treatment only in the soil from Onamudian. Adding sulphur increased plant growth only in the soil from Chelekura. Based on total biomass production, it appears that multiple nutrients limit productivity of millet on the degraded fields but that plant growth response depended on the interactions of $\mathrm{N} \times \mathrm{P} \times \mathrm{S}$ in Chelekura and $\mathrm{N} \times \mathrm{P} \times \mathrm{K}$ in Onamudian village. These combinations respectively resulted in 63 and 74\% of biomass yield on former kraals. Adding other cations $(\mathrm{Ca}$ and $\mathrm{Mg})$ or other micronutrients did not result in significant increases in biomass; to the contrary, they tended to give slightly depressed biomass yields.

\section{DISCUSSION}

Reversing nutrient depletion in smallholder farming systems is needed to assure food security for smallholders. Optimizing organic resources with inorganic nutrient sources together with improved germplasm and local adaptions can lead to restorative improvements of soil productivity (Vanlauwe et al., 2010). Knowledge on how to target nutrient resources is critical and using benchmarks within farming systems could be more realistic to evaluate the potential of nutrient interventions. In the Teso farming system, former kraal sites are the best for high productivity of finger millet and we used them as a benchmark

Application of $\mathrm{N}$ and $\mathrm{P}$ is recommended for improved millet productivity in the Teso farming system (Wortmann and Eledu, 1999). In this study, biomass production and yield of finger millet responded strongly when both $\mathrm{N}$ and $\mathrm{P}$ were supplied to the degraded fields, but in no case did yields match those found when finger millet was grown on former kraal sites. These former kraal sites are areas where manure has been accumulated over long periods of time through night corralling of cattle, although none of the sites where the experiments were situated had been used by cattle in the previous 5 years before this study. Persistence of good fertility in soils for at least four decades where kraals were formerly located has been reported from East Africa (Augustine, 2003).

The seasonal differences in millet yield response were strongly influenced by rainfall. No yield was obtained in the first season (2005B) due to drought. Yield and growth response in the subsequent season 2006A was dependent on nutrients applied as fertilizer and manure in the poor season (2005B), and thus observed variability in responses in 2006A may have been due to variability in nutrient losses. Although fertilizers and manure were applied again in the 2006B season, excessive rainfall (Figure 1) is likely to have caused substantial losses of N. Despite the excessive rainfall, strong responses in growth and yield of finger millet to combined applications of $\mathrm{N}$ and $\mathrm{P}$ were observed 


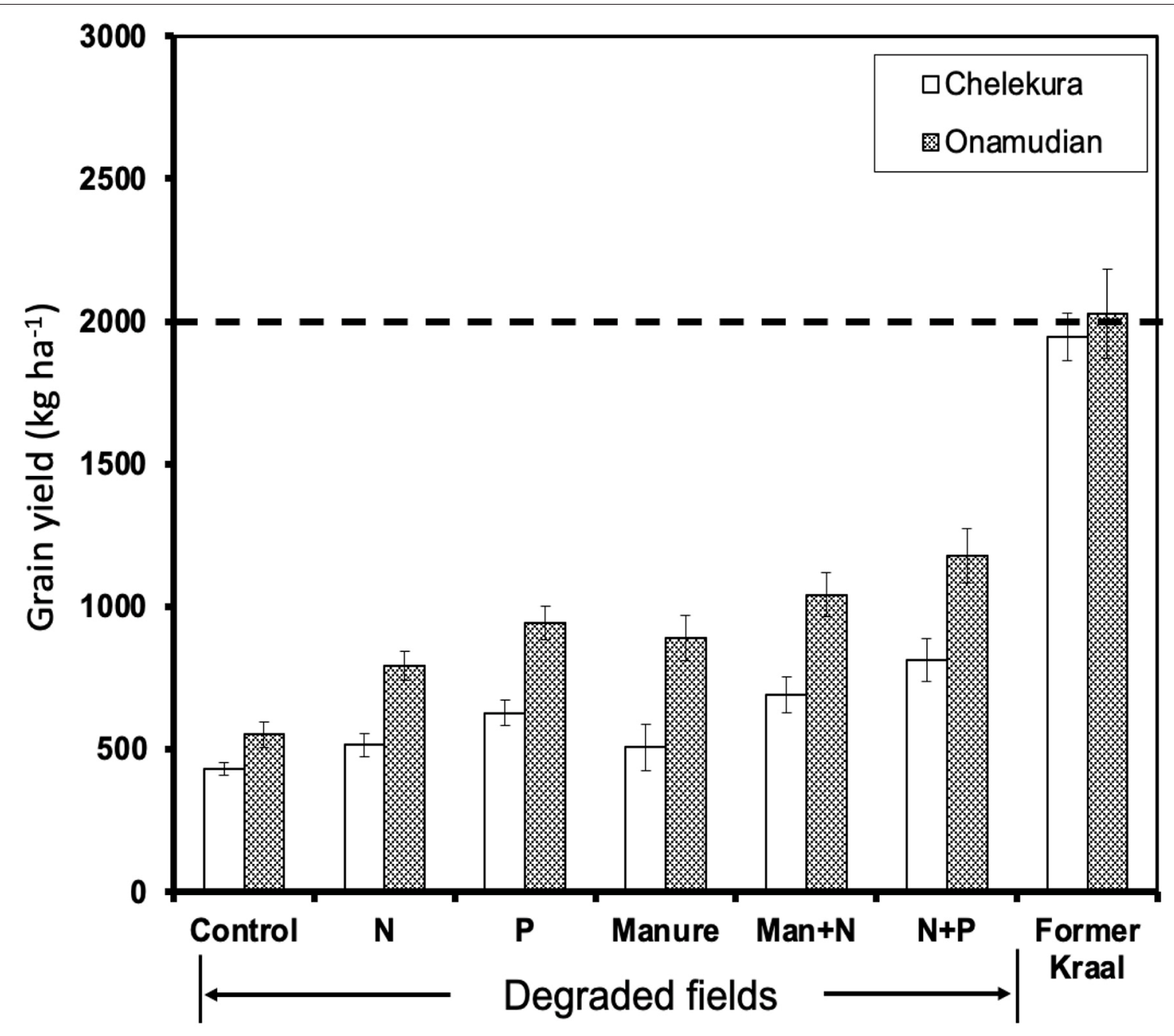

FIGURE 4 | Average responses of finger millet grain yields per applied treatment on degraded fields in comparison with the former kraal sites in the study villages, 2006. Bars are SEM.

in both 2006 seasons, although yields obtained were often only half those observed in the former kraal sites.

Soils differed between the two villages: the soils in Onamudian had greater silt+clay content (36\%; sandy loam) than for those in Chelekura (31\%; sandy clay loam). Silt + clay determine organic carbon storage through influencing physical protection of soil organic matter (Feller and Beare, 1997). In turn, these properties determine the capacity of soils to retain and supply cations. The soils in the former kraal sites had twice to three times as much SOC compared with the degraded fields in each of the landscape positions of each village. Variations in soil quality of former kraals between villages were also equally influenced by the differences in percent silt + clay of the soils, but could also vary due to different amounts of manure previously accumulated in those sites.

The effect of landscape position on millet response to fertilizer application was negligible and has been reported before in the area for legume-finger millet rotations (Ebanyat et al., 2010b). It implies that there is no strong soil fertility gradient in the villages but rather within locality or farm variability is critical for targeting and design of intervention options. The heterogeneity has been reinforced by lack of use of nutrient inputs affecting nutrient use efficiencies.

Internal, agronomic, and recovery efficiencies were generally low and explain the low millet yield response (Figures 2, 3). Better responses have been associated with higher indigenous supply of nutrients (Xu et al., 2015), through increased availability of nutrients. Further, manure treatments often resulted in higher agronomic and recovery efficiencies of $\mathrm{N}$ and $\mathrm{P}$ through increased total amounts of nutrients and probably improved moisture availability. It should, however, be noted that the high $\mathrm{PhEP}$ for manure treatments is because of the small amounts of $\mathrm{P}$ supplied under conditions of $\mathrm{P}$ deficiency. Combining $\mathrm{N}$ and $\mathrm{P}$ improved agronomic and internal efficiencies of $\mathrm{N}$ indicating co-limitations of the two nutrients (Figure 5). Phosphorus provides energy for nitrate reduction promoting $\mathrm{N}$ uptake and utilization in plants (Gupta et al., 2014), hence a better agronomic $\mathrm{N}$ efficiency when $\mathrm{N}$ is combined with P. Agronomic P efficiencies were higher 


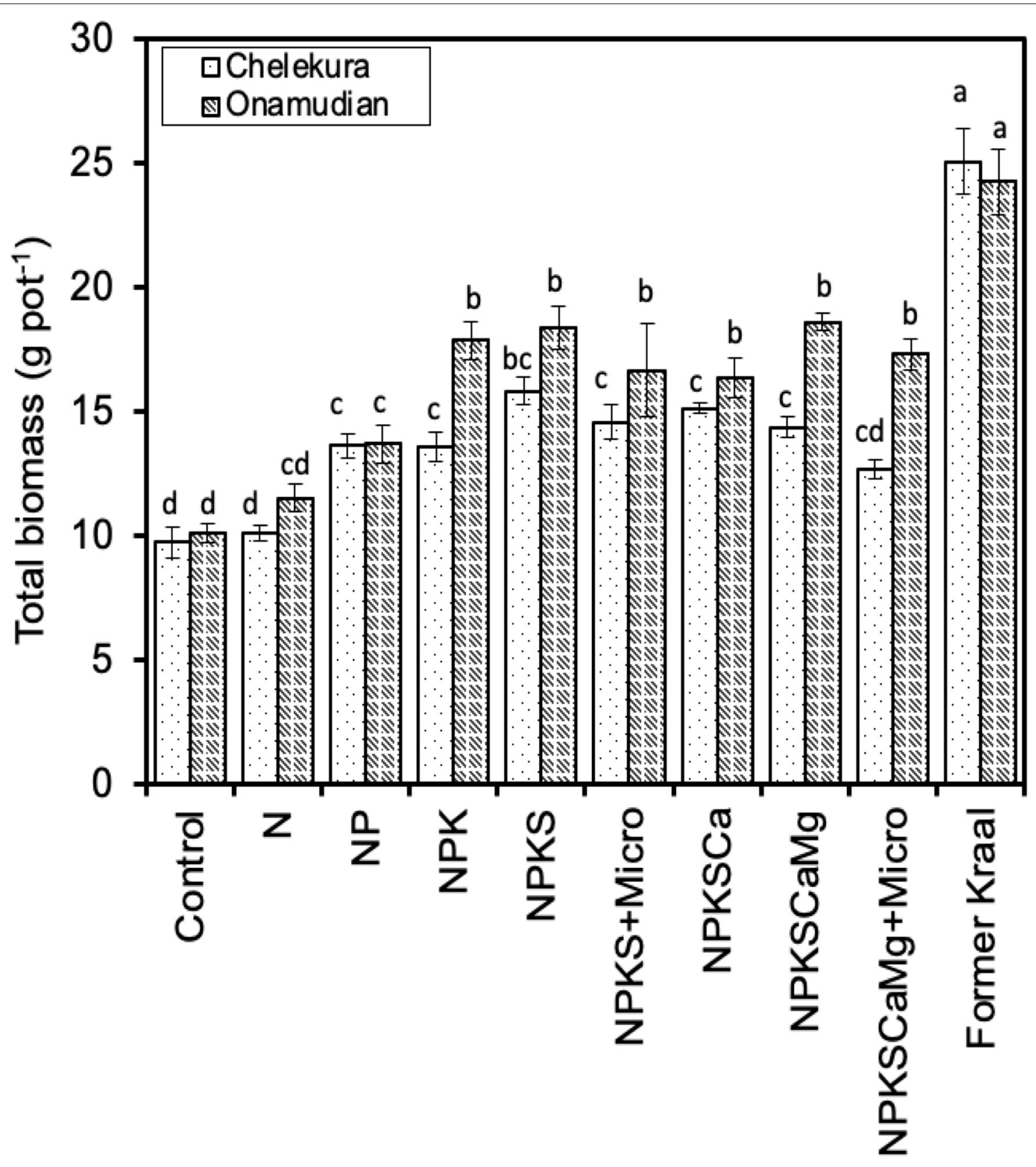

FIGURE 5 | Response of millet total biomass on soils from degraded fields from study villages amended with macro- and micronutrients and on former kraal soils in a greenhouse pot experiment over 8 weeks of growth. Bars are SEM. SE bars with same letters are not different.

in manure treatments probably because manure enhanced $\mathrm{P}$ availability as reflected in the higher ARP from the same treatments (Tables 3, 4). This highlights an important role for manure in improving nutrient availability in the degraded fields.

The two nutrients alone, however, resulted in $<45 \%$ of yields on former kraals (Figure 4) due to other constraints. Multiple nutrient deficiencies of $\mathrm{N}, \mathrm{P}, \mathrm{Ca}$, and $\mathrm{Zn}$ were reported to constrain rehabilitation of productivity on degraded sandy soils in Zimbabwe (Zingore et al., 2008). The limiting nutrient experiment that we conducted in pots showed that $\mathrm{S}$ and $\mathrm{K}$ were additionally limiting millet growth in soils from Pallisa (Figure 5). We had expected that treatments where manure was added would have supplied other nutrients such as K, S, and micronutrients, but it seems that manure was unable to provide sufficient quantities of these nutrients in the short term. In field experiments in Zimbabwe, responses in growth and yield of maize to old kraal manure were seen only in the third year after application (Nyamangara et al., 2005; Zingore et al., 2007). 
We further observed yield declines when $\mathrm{P}$ was applied at rates above $60 \mathrm{~kg} \mathrm{Pha}^{-1}$ that may be associated with $\mathrm{Zn}-\mathrm{P}$ antagonism arising from precipitation of zinc phosphate (Marschner, 1995). Soil organic matter also determines the physical properties of soils. The soils in the area are prone to surface sealing and often crusts are observed following rain events. Enhanced soil organic matter contents can improve the water balance in the degraded fields by reducing the susceptibility to crusting and enhancing infiltration. The good productivity of finger millet on the former kraal sites could be attributed to the beneficial effects of manure on many aspects of soil fertility: improving structure, moisture availability, nutrient availability including micronutrient supply, and biological activity, which can enhance nutrient cycling.

It is noteworthy that the conditions created in soils at former kraals arise from long-term accumulation of manure. Improving the conditions in the degraded fields will therefore require substantial time and large applications of manure. The quantities of manure available in this region are limited and difficult to increase - the smallholder farmers lack grazing land to feed cattle producing manure (Ebanyat, 2009), which means that more cattle cannot be supported in the area. Fertilizer use and recovery efficiencies were low probably because of the low SOC in the degraded fields and other losses. Rehabilitation of the degraded fields will require building up of organic matter to thresholds that can enhance fertilizer use efficiencies (Tittonell et al., 2007; Musinguzi et al., 2016), but it is unclear how the required amounts of organic matter can be sourced or created.

Attention to balanced crop nutrition, ensuring that fertilizers supply all of the necessary nutrients for crop growth, may give sufficient crop residues, which, if returned to the soil, may contribute to increase soil organic matter contents. Our results indicate that the declaration of the African Fertilizer Summit made in Abuja 2006 to aim for farmers to use $50 \mathrm{~kg}$ of fertilizer per hectare needs careful consideration because it will not yield much unless degraded fields are first rehabilitated. Responses of finger millet differed between sites with fields in the Chelekura site being less responsive compared with Onamudian because of the initial soil quality. The degraded fields in Onamudian had higher amounts of SOC compared with Chelekura (Table 1). Different amounts of inputs are required to raise productivity of fields in these two different villages reiterating the need for site-specific nutrient management and that such blanket fertilizer recommendations are inappropriate. Our experiments over three seasons yielded reasonable responses to fertilizers and manure, and from the knowledge that the process of rehabilitation takes time, dynamic modeling may help in designing strategies for intensification (e.g., Tittonell et al., 2008). Further experimentation is required to determine the quantities of organic manure and nutrients needed and the period it may take to restore fertility. Further field experiments are needed to assess the effects of application of all the limiting nutrients, including $\mathrm{S}, \mathrm{K}$, and micronutrients, on millet yield in the degraded fields.

\section{CONCLUSION}

Although growth and grain yield of finger millet in degraded soils were increased strongly by application of fertilizer and manure, none of the treatments could completely close the difference in yields obtained on sites of former kraals. The short-term nature of the experimentation, covering only three seasons, was insufficient to restore fertility of these degraded soils, even where cattle manure was applied in farmer's fields. The amounts of manure accumulated in former kraal sites were very large compared with the amounts added in the experiments, and probably insufficient to address the multiple nutrient limitations of $S$ and $K$. Combined application of $\mathrm{N}+\mathrm{P}$ fertilizer gave the strongest yield response compared with other options, but the strength of the crop response was variable with season, soil type, and, to a lesser extent, landscape position. Management aimed at increasing nutrient recovery efficiencies will need to accompany technological interventions to enhance sustainability. Thus, combining organic and inorganic resources (integrated nutrient management) because of their complementary benefits could lead to improved productivity of the degraded fields. Repeated applications of manure would be required to increase soil organic matter contents sufficiently to assist in improving capture (infiltration) and storage of water. The scarcity of manure in the area, due to the small number of cattle and the lack of grazing land, means that other means to restore soil organic matter contents of the soils and supply of other limiting nutrients must be sought.

\section{DATA AVAILABILITY STATEMENT}

The raw data supporting the conclusions of this article will be made available by the authors, without undue reservation.

\section{AUTHOR CONTRIBUTIONS}

PE: field experimentation, data collection, analysis, and drafting of manuscript. NR, MB, KG, and RD: conceptualization and design experiments and editing of article. All authors contributed to the article and approved the submitted version.

\section{FUNDING}

The field work was funded by the Rockefeller Foundation through the INSPIRE project, and the greenhouse experiments were funded by the Sida/SAREC small grants to the Faculty of Agriculture, Makerere University.

\section{ACKNOWLEDGMENTS}

We thank Patrick Okiring and Michael Orikoi for assistance with field experiments, Francis Ogwang for managing the greenhouse experiments, and farmers for availing land for experimentation. 


\section{REFERENCES}

Anderson, J. M., and Ingram, J. S. I. (1993). Tropical Soil Biology and Fertility. A Handbook of Method (2nd ed.). Wallingford: CAB International.

Augustine, D. J. (2003). Long-term, livestock-mediated redistribution of nitrogen and phosphorus in an East African savanna. J. Appl. Ecol. 40, 137-149. doi: 10.1046/j.1365-2664.2003.00778.x

Barret, C. B., Christiaensen, L., and Sheahan, M., Shimeles., A. (2017). On Structural Transformation of Rural Africa. Washington, D.C.: The World Bank.

Barungi, M. (2012). Constraints to fertiliser Use in Uganda: insights from uganda census of agriculture 2008/2009. J. Sustain. Develop. 5, 99-113 doi: 10.5539/jsd.v5n10p99

Bonilla Cedrez, C., Chamberline, J., Guo, Z., and Hijmans, R. J. (2020). Spatial variation in fertiliser prices in sub-Saharan Africa. PLOS ONE 15:e0227764. doi: 10.1371/journal.pone.0227764

Buresh, R. J., Sanchez, P. A., and Calhoun, F. (1997). Replenishing Soil Fertility in Africa. Madison, WI: SSSA, Special Publication No 51.

Chianu, J. N., Chianu, J. N., and Mairura, F. (2012). Mineral fertilisers in farming systems of sub-Saharan Africa: a review. Agron. Sustain. Develop. 32, 545-566. doi: 10.1007/s13593-011-0050-0

Chivenge, P., Vanlauwe, B. J., and Six, J. (2011). Does the combined application of organic and mineral nutrient sources influence maize productivity? a metaanalysis. Plant Soil 342, 1-30. doi: 10.1007/s11104-010-0626-5

Ebanyat, P. (2009). A Road to Food- Efficacy of Nutrient Management Options Targeted to Heterogeneous Soilscapes in the Teso Farming System, Uganda. $\mathrm{PhD}$ Thesis Wageningen University, The Netherlands.

Ebanyat, P., De Ridder, N., De Jager, A., Delve, R. J., Bekunda, M. A., and Giller, K. E. (2010a). Drivers of land use change and household determinants of sustainability in smallholder farming systems of Eastern Uganda. Popul. Environ. 31, 474-506. doi: 10.1007/s11111-010-0104-2

Ebanyat, P., De Ridder, N., De Jager, A., Delve, R. J., Bekunda, M. A., and Giller, K. E. (2010b). Impacts of heterogeneity in soil fertility on legume-finger millet productivity, farmers' targeting and economic benefits. Nutr. Cycl. Agroecosyst. 87, 209-231. doi: 10.1007/s10705-009-9329-9

Esele, J. P. (1989). Cropping systems, production technology, pests and diseases of finger millet in Uganda. in Small Millets in Global Agriculture, eds A. Segal, K. W. Riley, G. Harinarayana (New Delhi, Oxford and IBH Publishing Co. Pvt. Ltd.), 293-300.

Feller, C., and Beare, M. H. (1997). Physical control of soil organic matter dynamics in the tropics. Geoderma 79, 69-116. doi: 10.1016/S0016-7061(97)00039-6

Gupta, S., Gupta, S. M., Gupta, A. K., Gaur, V. S., and Kumar, A. (2014). Fluctuation of Dof1/Dof2 expression ratio under the influence of varying nitrogen and light conditions: Involvement in differential regulation of nitrogen metabolism in two genotypes of finger millet (Eleusine coracana L.). Gene 546, 327-335. doi: 10.1016/j.gene.2014.05.057

Harrop, J. (1970). "Soils," in Agriculture in Uganda, eds J.D. Jameson (Oxford: Oxford University Press), 43-71.

Holden, S. T. (2018). Fertiliser and sustainable intensification in sub-Saharan Africa. Glob. Food Secur. 18, 20-26. doi: 10.1016/j.gfs.2018.07.001

Kidoido, M. M., Kasenge, V., Mbowa, S., Tenywa, J. S., and Nyende, P. (2002). socioeconomic factors associated with finger millet production in eastern Uganda. Afr. Crop Sci. J. 10, 111-120. doi: 10.4314/acsj.v10i1.27561

Kihara, J., Nziguheba, G., Zingore, S., Coulibaly, A., Esilaba, A., Kabambe, V., et al. (2016). Understanding variability in crop response to fertiliser and amendments in sub-Saharan Africa. Agric. Ecosyst. Environ. 229:1-12. doi: 10.1016/j.agee.2016.05.012

Kihara, J., Weldesemayat Sileshi, G., Nziguheba, G., Kinyua, M., Zingore, S., and Sommer, R. (2017). Application of secondary nutrients and micronutrients increases crop yields in SSA. Agronomy for Sustainable development. Agron. Sustain. Develop. 37:25. doi: 10.1007/s13593-017-0431-0

Marschner, H. (1995). Mineral Nutrition of Higher Plants. London: Academic press.

Morris, M., Kelly, A. V., Kopicki, R. J., and Byerlee, D. (2007). Fertilizer Use in African Agriculture-Lessons Learned and Good Practice Guidelines. Washington DC: The World Bank.

Mueller, N. D., Gerber, J. S., Johnston, M., Ray, D. K., Ramankutty, N., and Foley, J. A. (2012). Closing yield gaps through nutrient and water management. Nature 490, 254-257. doi: 10.1038/nature11420
Musinguzi, P., Ebanyat, P., Tenywa, J. S., Basamba, T. A., Tenywa, M. M., and Mubiru, N. D. (2016). Critical soil organic carbon range for optimal crop response to mineral fertiliser nitrogen on a ferralsol. Experim. Agric. 52, 635-653. doi: 10.1017/S0014479715000307

Ndungu-Magiroi, K. W., Kasozi, A., Kaizzi, K. C., Mwangi, T., Koech, M., Kibunja, C. N., et al. (2017). Finger millet response to nitrogen, phosphorus and potassium in Kenya and Uganda. Nutr. Cycl. Agroecosyst. 108, 297-308. doi: 10.1007/s10705-017-9857-7

Nyamangara, J., Mudhara, M., and Giller, K. E. (2005). Effectiveness of cattle manure and nitrogen fertilizer application on the agronomic and economic performance of maize. South Afric. J. Plant Soil 22, 59-63. doi: 10.1080/02571862.2005.10634682

Ollier, C. D., Lawrence, C. J., Beckett, P. H. T., and Webster, R. (1969). Terrain Classification and Data Storage, Land Use Systems of Uganda. MEXE, Report No 959. Department of Agriculture, University of Oxford, Christchurch, Hampshire, England.

Orr, B. J., Cowie, A. L., Castillo Sanchez, V. M., Chasek, P., Crossman, N. D., Erlewein, A., et al. (2017). Scientific Conceptual Framework for Land Degradation Neutrality. A Report of the Science-Policy Interface. United Nations Convention to Combat Desertification (UNCCD), Bonn, Germany.

Owere, L., Tongoona, P., Derera, J., and Wanyera, N. (2014). Farmers' perceptions of finger millet constraints, varietal preferences and their implications to finger millet breeding in Uganda. J. Agric. Sci. 6:126. doi: 10.5539/jas.v6n12p126

Ridder, N., de, Breman, H., Keulen, H., and van, Stomph, T. J. (2004). Revisiting a 'cure against land hunger': soil fertility management and farming systems dynamics in the West African Sahel. Agric. Syst. 80, 109-131. doi: 10.1016/j.agsy.2003.06.004

Rowe, E. C., Wijk, M. T., van, Ridder, N., and de, Giller, K. E. (2006). Nutrient allocation strategies across a simplified heterogeneous African smallholder farm. Agric. Ecosyst. Environ. 116, 335-345. doi: 10.1016/j.agee.2006.03.019

Shepherd, K. D., Palm, C. A., Gachengo, C. N., and Vanlauwe, B. (2003). Rapid characterization of organic resource quality for soil and livestock management in tropical agro-ecosystems using near infrared spectroscopy. Agron. J. 95, 1314-1322. doi: 10.2134/agronj2003.1314

Shepherd, K. D., and Walsh, M. G. (2002). Development of reflectance libraries for characterisation of soil properties. Soil Sci. Soc. Am. J. 66, 988-998. doi: 10.2136/sssaj2002.9880

Smaling, E. M. A., Nandwa, S. M., and Janssen, B. H. (1997). "Soil fertility in Africa is at stake," in Replenishing Soil Fertility in Africa, eds R.J. Buresh, P.A. Sanchez and F. Calhoun (Madison, WI: SSSA, Special Publication), 47-61.

Stewart, Z. P., Pierzynski, G. M., Jan Middendorf, B., and Vara Prasad, P. V. (2020). Approaches to improve soil fertility in sub-Saharan Africa. J. Exp. Bot. 71, 632-641. doi: 10.1093/jxb/erz446

Tenywa, J. S., Nyende, P., Kidoido, M., Kasenge, V., Oryokot, J., and Mbowa, S. (1999). Prospects and constraints for finger millet production in eastern Uganda. Afr. Crop Sci. J. 7, 31-35. doi: 10.4314/acsj.v7i4.27751

Tittonell, P. (2008). Musimu wa Kupanda- Targeting resources within diverse, heterogeneous and dynamic farming systems of East Africa. PhD Thesis, Wageningen University, Wageningen, The Netherlands.

Tittonell, P., Corbeels, M., Wijk, M. T., van, Vanlauwe, B., and Giller, K. E. (2008). Combining organic and mineral fertilizers for integrated soil fertility management in smallholder farming systems of Kenya explorations using the crop-soil model FIELD. Agron. J. 100, 1511-1526. doi: 10.2134/agronj2007.0355

Tittonell, P., Zingore, S., Wijk, M. T., van, Corbeels, M., and Giller, K. E. (2007). Nutrient use efficiencies and crop responses to N, P and manure applications in Zimbabwean soils: exploring management strategies across soil fertility gradients. Field Crops Res. 100, 348-368. doi: 10.1016/j.fcr.2006.09.003

Uganda Bureau of Statistics (UBOS) (2020). Uganda Annual Agricultural Survey 2018. Kampala, Uganda

Vanlauwe, B., Bationo, A., Chianu, J., Giller, K. E., Merckx, R., Mokwunye, U., et al. (2010). Integrated soil fertility management: Operational definition and consequences for implementation and dissemination. Outlook Agric. 116:998. doi: 10.5367/000000010791169998

Vanlauwe, B., Diels, J., Sanginga, N., and Merckx, R. (2002). Integrated plant nutrient management in Sub-Saharan africa. from concepts to practice. $C A B$ International Wallingford, UK. 
Wanyera, N. M. W. (2007). "Finger Millet (Eleusine coracana (L.) Gaertn) in Uganda," in Creating Opportunities for Improving Production and Utilization of Finger Millet. Proceedings of the First International Finger Millet Stakeholder Workshop,eds M. A. Mgonja., J. M., Lenné, E. Manyasa., S. Sreenivasaprasad (DFID and ICRISAT), 1-9.

Wit, C. T. (1992). Resource use efficiency in agriculture. Agric. Syst. 40, 125-151. doi: 10.1016/0308-521X(92)90018-J

Witt, C. A., Dobermann, S., Abdulrachman, S., Gines, H. C., Guanghuo, W., Nagarajan, R., et al. (1999). Internal nutrient efficiencies in irrigated lowland rice of tropical and subtropical Asia. Field Crops Res. 63, 113-138. doi: 10.1016/S0378-4290(99)00031-3

Wortmann, C. S., and Eledu, C. A. (1999). Uganda's Agroecological Zones: A guide for Planners and Policy Makers. Uganda: CIAT Kampala.

Wortmann, C. S., Kaizzi, K. C., Maman, N., Cyamweshi, A., Dicko, M., Garba, M., et al. (2019). Diagnosis of crop secondary and micro-nutrient deficiencies in sub-Saharan Africa. Nutr. Cycl. Agroecosyst. 113, 127-140. doi: 10.1007/s10705-018-09968-7

Xu, X., Liu, X., He, P., Johnston, A. M., Zhao, S., Qiu, S., et al. (2015). Yield gap, indigenous nutrient supply and nutrient use efficiency for maize in China. PLoS ONE 10:e0140767. doi: 10.1371/journal.pone.01 40767

Yost, D., and Eswaran, H. (1990). Major Land Resource Areas of Uganda. Washington, DC: World Bank.

Zingore, S., Delve, R. J., Nyamangara, J., and Giller, K. E. (2008). Multiple benefits of manure: the key to maintenance of soil fertility and restoration of depleted sandy soils on African smallholder farms. Plant Soil 80, 267-282. doi: 10.1007/s10705-007-9142-2

Zingore, S., Murwira, H. K., Delve, R. J., and Giller, K. E. (2007). Soil type, historical management and current resource allocation: Three dimensions regulating variability of maize yields and nutrient use efficiencies on African smallholder farms. Field Crops Res. 101, 296-305. doi: 10.1016/j.fcr.2006.12.006

Conflict of Interest: The authors declare that the research was conducted in the absence of any commercial or financial relationships that could be construed as a potential conflict of interest.

Publisher's Note: All claims expressed in this article are solely those of the authors and do not necessarily represent those of their affiliated organizations, or those of the publisher, the editors and the reviewers. Any product that may be evaluated in this article, or claim that may be made by its manufacturer, is not guaranteed or endorsed by the publisher.

Copyright (c) 2021 Ebanyat, de Ridder, Bekunda, Delve and Giller. This is an openaccess article distributed under the terms of the Creative Commons Attribution License (CC BY). The use, distribution or reproduction in other forums is permitted, provided the original author(s) and the copyright owner(s) are credited and that the original publication in this journal is cited, in accordance with accepted academic practice. No use, distribution or reproduction is permitted which does not comply with these terms. 